\title{
Nils Martola in memoriam
}

\section{Nekrolog}

DOI: https://doi.org/10.30752/nj.112286
$\mathrm{N}$ ils Martola, tidigare redaktör för Nordisk judaistik, avled i juli efter en tids sjukdom. Han föddes I 943, studerade teologi vid Åbo Akademi och disputerade 1984 på en avhandling om Första Mackabéerboken. Hans forskning fokuserade på klassiska judiska texter, av vilka han översatte en del till svenska. Efter olika anställningar vid Åbo Akademi övergick han i slutet av r 990-talet till tjänst inom den lutherska kyrkan i Finland.

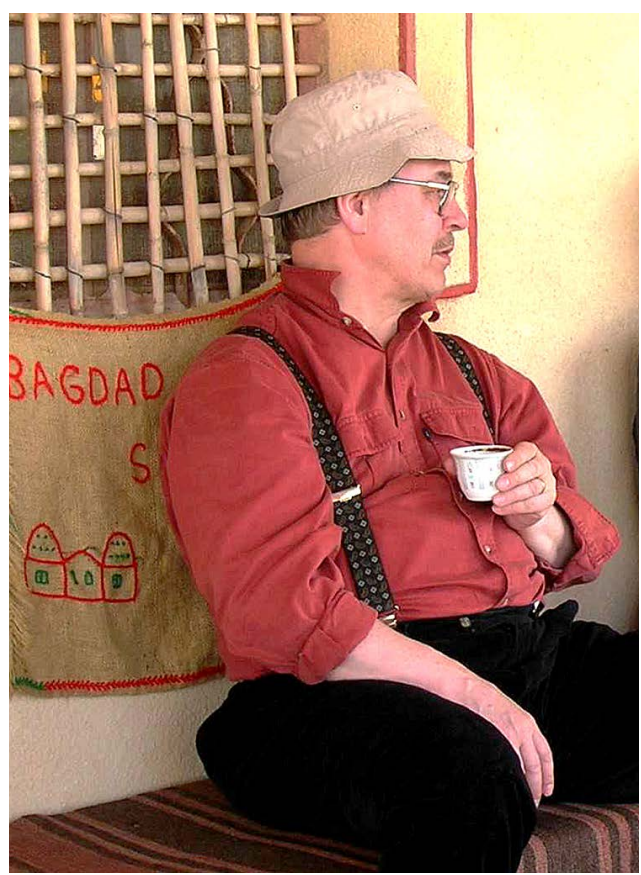

Nils Martola i Syrien 2005. Privat samling.
Sällskapet för judaistisk forskning hade grundats 1973 som en svensk organisation och från och med dess första kongress i Stockholm I975 var en av dess viktigaste uppgifter att utge Nordisk judaistik. I och med dess andra kongress r 98 I i Köpenhamn blev sällskapet nordiskt med styrelsemedlemmar också från Danmark, Finland och Norge. Från och med årsskiftet r 984-85 överflyttades redaktionen för Nordisk judaistik till Åbo och Nils Martola blev dess redaktör. I en programförklaring i nr. I/ 985 tackar han sin föregångare Svante Hansson som i tio år"lagt grunden till en tidskrift med höga vetenskapliga krav och en som ger uttryck för judaistikens mångfald”. Martola förklarar också att han står fast vid den programförklaring som uttryckts i tidskriftens första nummer, att den vill vara "ett forum för judaistisk forskning i Norden genom att publicera uppsatser med vetenskapliga ambitioner av nordiska författare eller av icke-nordiska författare i judaistiska ämnen med nordisk anknytning”.

Martola verkade som redaktör för Nordisk judaistik i sju år, till och med år r99r. Det blev sammanlagt I 3 nummer (två per år förutom I 990 då det utkom ett dubbelnummer). Under sin tid som redaktör bidrog han själv till tidskriften med sju artiklar och tio recensioner. När han på egen begäran avgick som redaktör uttryckte Sällskapets ordförande, 
professor Karl-Johan Illman, sin uppskattning på följande sätt: "Under denna tid [då Martola varit redaktör] har tidskriftens utgivning blivit betydligt stabilare och bidragens vetenskapliga nivå har snarare stigit än sjunkit. När man betänker att Martola skött utgivningen av tidskriften med allt vad därtill hör nära nog ensam och själv dessutom utfört formateringen av manuskripten för tryckning, blir man imponerad."

Nisse var som vetenskapsman stringent och noggrann. Akribin skulle vara felfri och källhänvisningarna korrekta. Tidigt blev han kunnig i hur den moderna teknologin kan underlätta arbetet för en forskare. Han kunde verka nördig och inåtvänd, men när han tillät sig att släppa loss var han social och underhållande. Vi som haft honom som lärare, förebild och vän känner stor saknad över att han inte längre finns ibland oss.

SVANTE LUNDGREN Docent i judaistik, Åbo Akademi och forskare vid Lunds universitet 